\title{
CON TEC LC LIGHT-CURING ADHESIVE IN ORTHODONTICS
}

\author{
V. Mirjanić, S. Čupić, V. Veselinović \\ University of Banja Luka, Faculty of Medicine, Department of Dentistry, \\ Save Mrkalja 14, Banja Luka, Republic of Srpska, B\&H
}

\begin{abstract}
This paper analyzes Con Tec LC light-curing adhesive which was used for bonding brackets to the teeth. Bonding of adhesive starts with the use of electromagnetic radiation, that is to say, ultraviolet light. The beginning of application of these adhesives was in the eighties of the last centuries 40 extracted teeth of frontal region were used for the analysis of tooth-bracket bond strength (the debonding force along the surface of the bracket-enamel interface). The debonding process of fixed orthodontic brackets, aimed at determining the strength of the force necessary to separate the bracket from tooth surface, was measured by way of single-axial Stretch System in the Centre for Bioengineering in Kragujevac. The tensile force was accomplished at the constant speed of $1 \mathrm{~mm} / \mathrm{min}$, while the device automatically recorded the force with $0.3 \mathrm{~N}$ accuracy. After conducted research, the obtained results were statistically processed and analyzed.

At the end of conducted analysis, clinical-technical implications of examined Con Tec LC adhesive are presented.
\end{abstract}

Keywords: Con Tec LC, adhesive, orthodontics.

\section{INTRODUCTION}

The analysis of the factors that determine the hardness, i.e. bond strength by which the bracket is adhered to the tooth, via adhesive, is a very complex one; it is not easy to exactly determine all these factors or objectivize them by a quantitative method.

There are only three factors frequently mentioned in literature as determining this strength, [1] namely: bracket base; tooth surface and type of adhesive material.

However, this would be relevant only in cases where bonding brackets was performed by always the same person in ideal (laboratory) conditions, i.e. in vitro, in which it would be possible to eliminate other occurring factors.

Without material for bonding brackets (adhesive), the work in fixed orthodontics would be impossible, and research in that field would be brought one step backwards - to using the bands for all teeth. On the other hand, the work with adhesives implies a lot of problems and risks, because we are here faced with contradictory demands by the therapists: the bracket should be bonded to the tooth by the strongest possible force so as to avoid bracket failure during work, that is to say, to make sure that the bracket can withstand the force produced by arches, rubber cups, springs and other active elements used for moving the tooth to the desired place. This however increases a risk that a therapist would like to avoid at any cost - tooth enamel damage and creation of defects that are frequently only visible macroscopically, during separation of brackets from the tooth (debonding). Newer adhesives have appeared designed for removing those deficiencies, so nowadays there is a multitude of various types of adhesive offered in the market, accompanied by aggressive advertising the advantages with overstating good characteristics while undervaluing disadvantages. Users of these materials are confused by such a situation, because, as stated above, the manufacturers' assertions of "significantly better" product do not correspond to the observations made in clinical work. It is noteworthy that these inconsistencies may partly be a result of the therapist's failure to follow the manufacturer's instructions in work, that a therapist should absolutely abide by.

All these were the reasons that made us undertake this study, as we wanted to arrive at exact facts that would be valid for making expert conclusions and reliable recommendations possible to be used in practical work in everyday practice. In order to understand this problematic better and appreciate all the problems in work with the adhesives, one should be thoroughly acquainted with all the types of adhesives that are currently used in everyday practice. 
All adhesives can be divided in two major groups, one according to the type of curing, and the other by the humidity of base, i.e. absence of humidity from surfaces on which brackets are bonded. The first group includes: chemically activated; light-curing; chemically and light-curing and thermally curing.

Another division with regards to humidity of the base includes: adhesives that are not sensitive to humid conditions and adhesives that are active in the presence of humidity.

We will here only present the method of work, advantages and disadvantages of Con Tec LC adhesives that are most frequently used nowadays, and that were the subject of the study in this paper.

With light-curing adhesives, bonding starts by electromagnetic radiation, i.e. ultraviolet light. The beginning of the use of these adhesives was in the eighties of the last century. As source of light both classic halogen source and any other light source used in dentistry for light-curing are used.

The advantage of these adhesives is in the fact that they made manipulation easier, because the time of start of adhesive "bonding" is determined by a therapist at the moment when he directs the beam of light for light-curing.

The order of actions during the use of these adhesives is as follows: etching of enamel, application of "bond", placing adhesive on the bracket, applying the bracket to the etched part of tooth and curing.

Most authors state that 40 seconds of exposure to the curing light is quite enough in terms of curing, with classic source of light used. It is important to describe here more thoroughly the technique itself of curing. With application of metal brackets the beam of curing light is directed during 10 seconds on each side of the bracket. However, if the brackets applied are made of ceramic or plastic, the light is directed straight onto it. Where LED light is used, the time of exposure of the bracket to the light may be reduced to 20 seconds [1,2]. The biggest advantage of this type of adhesive is that, during the time at which it is exposed to the light, the process of curing the adhesive is fully completed, which enables placing and connecting as a source of force directly after curing.

Using fixed technique in orthodontics has certain advantages as well as disadvantages compared to the mobile technique in therapy. One of major problems relatively frequently faced by an orthodontist in his daily work, during application of fixed technique, is the occurrence of "failure" of brackets placed on the tooth. This results in waste of time both for the patient and the therapist, because the bracket should be placed again, which in turn results in reduced ability of bonding bracket to the tooth compared to the previous placing.

Considering the importance of the problem, and frequently contradictory opinions about this disadvantage of the fixed technique, we started this study, aimed at determining the bracket-tooth bond strength accomplished with the use of Con Tec LC adhesive. Another goal of the study was to, based on the results obtained, give recommendations for practical work with the said adhesive, in terms of bracket-tooth bond strength and the degree of tooth dislocation.

\section{MATERIALS AND METHODS}

40 extracted teeth of the frontal region (central, lateral incisors and molars of upper and lower dental arch) were used for the analysis of bracket-tooth bond strength, during the use of Con Tec LC adhesive. The criteria for teeth selection for the study included:

- no caries on labial surface,

- no cracks of enamel caused by the pressure of forceps during tooth extraction,

- no hypoplastic macroscopically visible areas, and

- no decalcification caused by any reason.

The common procedure of tooth preparation for bonding brackets (regardless of type of adhesive), was in accordance with the most frequently used procedure for this type of in vitro studies [3-9].

The procedure consisted of storing the freshly extracted human teeth in a solution of $0,1 \%$ (weight/volume) thymol. Teeth were cleansed and polished. Only after the preparation thus made was the procedure of bonding brackets to the tooth applied (Figure 1).

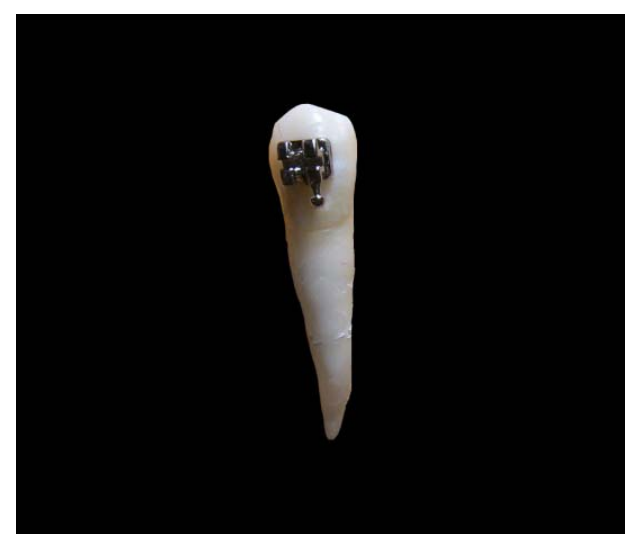

Figure 1. Bracket bonded on a molar (prepared for experimental analysis).

The protocol determined by the requirements, that is to say, manufacturer's instructions was used during bonding brackets. 
The study was done in vitro like this was done by many other researchers before [10-19]. An in vitro study of adhesives has advantages over an in vivo study, as the factor of speed of work connected to the dexterity of researcher is eliminated, thus excluding the possibility of contaminating the working area by saliva (which reduces the adhering power of adhesive), taking into account that most adhesives are sensitive to humidity as "one of the most common causes for bracket failure". In addition to that, laboratory studies may have significant clinical implications if certain conditions are ensured.

In order to avoid the influence of type of the bracket on bracket-tooth bond strength, the same type of metal bracket Discovery Slot 0,56 x $0,76 \mathrm{~mm}$ / $22 \times 30$ inch, Cuspid brackets with hooks was used with all tested teeth.

The process of debonding of placed orthodontic brackets aimed at determining the size of force necessary to separate the bracket from tooth surface was measured in the Centre for Bioengineering of Kragujevac University. For the purpose of this study the Centre for Bioengineering modified its device, a single-axial Stretch system for tissue testing [20,21]; a new sensor for $300 \mathrm{~N}$ force was mounted and used to test the force of separation of bracket from the tooth. The direction of application of debonding force was at 90 degrees angle on the vertical axis of the tooth.

Tensile force was achieved at constant speed of $1 \mathrm{~mm} / \mathrm{min}$. The device automatically recorded the force with $0,3 \mathrm{~N}$ accuracy. The forces in the function of time with 0.15 second intervals are presented in the graph. The bond strength (I) was calculated by dividing the debonding force (F) by the surface of adhering of the bracket to the tooth (S), i.e. $\mathrm{I}=\mathrm{F} / \mathrm{S}$. As the debonding force is expressed in Newtons (N), and surface in $\mathrm{mm}^{2}$, it follows that the bond strength will be expressed in MPa. The position of the tooth in the device Stretch system before starting debonding is presented in Figure 2.

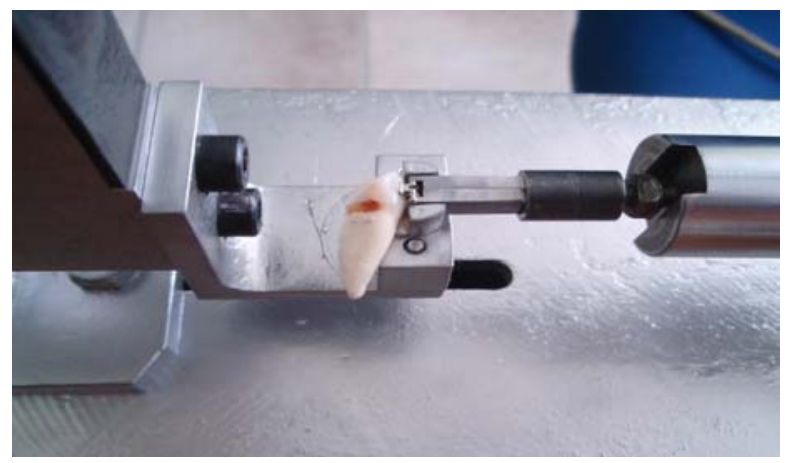

Figure 2. Position of the tooth in the device Stretch system, before starting debonding
After completion of the study, the results obtained were statistically processed and analyzed.

\section{RESULTS OF STUDY}

The results of debonding force $(\mathrm{N})$ and bracket-tooth bond strength (MPa) cumulatively for tested teeth of upper and lower dental arch with ConTec LC are presented in table 1.

The results of statistical analysis of debonding force are presented in table 2, and in table 3 the bond strengths accomplished with the adhesive ConTec LC.

Table 4 presents the distribution of values of bracket-tooth bond strength when using adhesive ConTec LC, where the interval range of bond strength is $1 \mathrm{MPa}$.

The results obtained show that the average value of bond strength of $6.71 \mathrm{MPa}$ (reflecting the adhesive power) for Con Tec LC adhesive have lower values compared to the results stated in [22]. In both studies the adhesive of the same manufacturer was used and the same manner of tooth preparation and with in vitro investigation applied. The difference in obtained values between these two studies may be explained to a certain extent by a selection of the teeth that were subject of research, because researchers in [22] conducted the study on pre-molars, while this study was conducted on molars and incisors of the upper and lower jaw. However, if we compare the results of the study in [22] with the results of other authors $[15,16]$ who conducted studies on the same teeth, the values that they arrived at are still significantly higher. When analyzing and discussing such high values arrived at by certain authors in in vitro studies, in terms of the debonding force, which indirectly reflects the adhesive power of adhesive, the following facts have to be taken into account: firstly, these values most probably would not be so high had the study been undertaken with the same adhesives but in in vivo conditions, because based on in vitro research protocol, we do not have all these negative factors adversely affecting the strength of bracket-tooth bond in the oral cavity (impossibility to ensure an absolutely dry operating area, impossibility of the patient to be absolutely calm, etc.). Secondly, if these results (during an in vivo study), were still higher than 14MPs, even with the decreasing of the stated values, that would take us to the other extreme: by decreasing the risk of unwanted bracket failure, the degree of risk for enamel damage during debonding would be increased, a fact that many authors point at as warning [11,23-28]. 
Table 1. Values of debonding force $(N)$ and bracket-tooth bond strength (MPa) for teeth of the upper and lower dental arch with application of adhesive Con Tec LC.

\begin{tabular}{|c|c|c|c|c|c|}
\hline \multicolumn{6}{|c|}{ ConTec LC adhesive } \\
\hline ConTec LC & Debonding force $(\mathrm{N})$ & Surface $\left(\mathrm{mm}^{2}\right)$ & $\begin{array}{l}\text { Bond strength } \\
(\mathrm{MPa})\end{array}$ & Dental arch & Type of tooth \\
\hline 18. & 42,43 & 9,37 & 4,53 & $\mathrm{D}$ & 1,2 \\
\hline 8. & 42,52 & 9,37 & 4,54 & $\mathrm{D}$ & 1,2 \\
\hline 28. & 42,61 & 9,37 & 4,55 & $\mathrm{D}$ & 1,2 \\
\hline 38. & 42,91 & 9,37 & 4,58 & $\mathrm{D}$ & 1,2 \\
\hline 3. & 49,03 & 9,37 & 5,23 & $\mathrm{D}$ & 1,2 \\
\hline 23. & 49,13 & 9,37 & 5,24 & $\mathrm{D}$ & 1,2 \\
\hline 33. & 49,81 & 9,37 & 5,32 & $\mathrm{D}$ & 1,2 \\
\hline 13. & 50,08 & 9,37 & 5,34 & $\mathrm{D}$ & 1,2 \\
\hline 17. & 54,89 & 9,37 & 5,86 & $\mathrm{D}$ & 1,2 \\
\hline 7. & 55,25 & 9,37 & 5,90 & $\mathrm{D}$ & 1,2 \\
\hline 27. & 55,28 & 9,37 & 5,90 & $\mathrm{D}$ & 1,2 \\
\hline 37. & 55,81 & 9,37 & 5,96 & $\mathrm{D}$ & 1,2 \\
\hline 15. & 57,96 & 9,37 & 6,19 & $\mathrm{D}$ & 1,2 \\
\hline 5. & 58,21 & 9,37 & 6,21 & $\mathrm{D}$ & 1,2 \\
\hline 25. & 58,46 & 11,44 & 5,11 & $\mathrm{D}$ & 3 \\
\hline 35. & 58,81 & 11,44 & 5,14 & $\mathrm{D}$ & 3 \\
\hline 22. & 63,73 & 11,44 & 5,57 & $\mathrm{D}$ & 3 \\
\hline 2. & 63,84 & 11,44 & 5,58 & $\mathrm{D}$ & 3 \\
\hline 12. & 64,18 & 11,44 & 5,61 & $\mathrm{D}$ & 3 \\
\hline 32. & 64,81 & 11,44 & 5,67 & $\mathrm{D}$ & 3 \\
\hline 30. & 82,98 & 12,50 & 6,64 & $\mathrm{H}$ & 2 \\
\hline 10. & 83,08 & 12,50 & 6,65 & $\mathrm{H}$ & 2 \\
\hline 40. & 83,11 & 12,50 & 6,65 & $\mathrm{H}$ & 2 \\
\hline 20. & 83,15 & 12,50 & 6,65 & $\mathrm{H}$ & 2 \\
\hline 6. & 90,49 & 12,50 & 7,24 & $\mathrm{H}$ & 2 \\
\hline 26. & 90,51 & 12,50 & 7,24 & $\mathrm{H}$ & 2 \\
\hline 36. & 90,59 & 12,50 & 7,25 & $\mathrm{H}$ & 2 \\
\hline 16. & 91,05 & 12,50 & 7,28 & $\mathrm{H}$ & 2 \\
\hline 9. & 104,11 & 12,61 & 8,26 & $\mathrm{H}$ & 3 \\
\hline 19. & 105,06 & 12,61 & 8,33 & $\mathrm{H}$ & 3 \\
\hline 29. & 105,13 & 12,61 & 8,34 & $\mathrm{H}$ & 3 \\
\hline 39. & 105,81 & 12,61 & 8,39 & $\mathrm{H}$ & 3 \\
\hline 14. & 113,98 & 12,61 & 9,04 & $\mathrm{H}$ & 3 \\
\hline 4. & 114,77 & 12,61 & 9,10 & $\mathrm{H}$ & 3 \\
\hline 24. & 114,96 & 13,12 & 8,76 & $\mathrm{H}$ & 1 \\
\hline 34. & 115,07 & 13,12 & 8,77 & $\mathrm{H}$ & 1 \\
\hline 11. & 117,13 & 13,12 & 8,93 & $\mathrm{H}$ & 1 \\
\hline 21. & 118,21 & 13,12 & 9,01 & $\mathrm{H}$ & 1 \\
\hline 1. & 118,32 & 13,12 & 9,02 & $\mathrm{H}$ & 1 \\
\hline 31. & 118,57 & 13,12 & 9,04 & $\mathrm{H}$ & 1 \\
\hline
\end{tabular}

Namely, the purpose of these studies was also to determine the average bond strength achieved between the bracket and the tooth with various types of teeth, because arch activation most frequently has the same effect on all brackets "threatening" to separate the bracket from the tooth. Based on results obtained, we can obtain indicative values for practical work, because, during arch activation we must abide by the information as to which is the strongest force of the bonded arch that can be applied without having a bracket failure, i.e. which is a force that the bracket can withstand without falling off from the tooth and that has the lowest values of bond strength. In other words, the size of the bracket, i.e. the size of its interface with the tooth and the type of the tooth where we find the highest values of bond strength, cannot serve as benchmark. The average values of bond strength obtained for the teeth of the 
front that were the subject of study (molars and incisors), which ranged in the interval from 5,93 to 9,93 $\mathrm{MPa}$, for tested adhesive, are within a range stated by most authors as desirable and sufficient for orthodontic treatment by fixed technique [29].

Table 2 Results of statistical analysis of debonding force for adhesive ConTec LC

\begin{tabular}{|c|c|c|c|}
\hline \multirow{2}{*}{$\begin{array}{c}\text { Descriptive parameter } \\
\text { (Debonding force (N) - } \\
\text { adhesive ConTecLC) }\end{array}$} & Upper & Lower & \multirow{2}{*}{ Total } \\
\cline { 3 - 4 } & Dental arch & \\
\hline N & 20 & 20 & 40 \\
\hline MIN & 82,98 & 42,43 & 42,43 \\
\hline MAX & 118,6 & 64,81 & 118,57 \\
\hline I & 35,59 & 22,38 & 76,14 \\
\hline Mo & - & - & - \\
\hline Me & 105,1 & 55,27 & 73,90 \\
\hline Xsr & 102,3 & 53,99 & 78,15 \\
\hline SD & 13,88 & 7,59 & 26,84 \\
\hline CV & 13,57 & 14,06 & 34,35 \\
\hline
\end{tabular}

Table 3. Results of statistical analysis of bond strength accomplished with adhesive ConTec LC

\begin{tabular}{|c|c|c|c|}
\hline \multirow{2}{*}{$\begin{array}{c}\text { Descriptive parameter } \\
\text { (Bond strength (MPa) - } \\
\text { adhesive ConTecLC) }\end{array}$} & \multicolumn{2}{|c|}{ Dental arch } & \multirow{2}{*}{ Total } \\
\cline { 2 - 3 } & Upper & Lower & \\
\hline N & 20,00 & 20 & 40 \\
\hline MIN & 6,64 & 4,53 & 4,53 \\
\hline MAX & 9,10 & 6,21 & 9,10 \\
\hline I & 2,46 & 1,68 & 4,57 \\
\hline Mo & - & - & - \\
\hline Me & 8,33 & 5,46 & 6,43 \\
\hline Xsr & 8,03 & 5,40 & 6,71 \\
\hline SD & 0,96 & 0,54 & 1,54 \\
\hline CV & 11,94 & 10,04 & 22,89 \\
\hline
\end{tabular}

Table 4. Distribution of values of bracket-tooth bond strength when using adhesive ConTec LC. The interval range of the bond strength $1 \mathrm{MPa}$.

\begin{tabular}{|c|c|c|c|c|c|c|c|c|c|}
\hline \multirow[b]{2}{*}{ 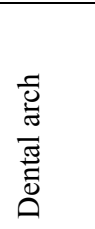 } & \multicolumn{8}{|c|}{ Bond strength (MPa) } & \multirow[b]{2}{*}{$\stackrel{\overline{0}}{0}$} \\
\hline & $\begin{array}{l}8 \\
\stackrel{\nabla}{v}\end{array}$ & $\begin{array}{l}8 \\
8 \\
i \\
8 \\
8 \\
8\end{array}$ & $\begin{array}{l}8 \\
8 \\
0 \\
1 \\
0 \\
0\end{array}$ & $\begin{array}{l}8 \\
0 \\
1 \\
0 \\
0\end{array}$ & $\begin{array}{l}8 \\
0 \\
\infty \\
1 \\
0 \\
0\end{array}$ & $\begin{array}{l}8 \\
0 \\
0 \\
0 \\
\infty\end{array}$ & $\begin{array}{l}8 \\
0 \\
0 \\
1 \\
0 \\
0 \\
0\end{array}$ & $\begin{array}{l}8 \\
0 \\
0 \\
\wedge\end{array}$ & \\
\hline Upper & 0 & 0 & 0 & 4 & 4 & 7 & 5 & 0 & 20 \\
\hline Lower & 0 & 4 & 14 & 2 & 0 & 0 & 0 & 0 & 20 \\
\hline Total & 0 & 4 & 14 & 6 & 4 & 7 & 5 & 0 & 40 \\
\hline
\end{tabular}

Comparison of the results of bond strength in this study, which used the molars, lateral and central upper and lower incisors with the results arrived at by Newman and al [20], while using central and lateral incisors, shows that the results obtained are similar to the above results.

\section{CONCLUSION}

The above results give a clear picture about the bracket-tooth bond strength, which is accomplished by tested adhesive that is most frequently used in practice nowadays; they have the following clinical-theoretical implications. If a degree of tooth dislocation is lower, which demands smaller arch activation, i.e. lower force to move the tooth, an adhesive the application of which creates smaller brackettooth strength should be used (Con Tec LC).

\section{REFERENCES}

[1] D. Demirović, Osnovi fiksne tehnike u ortodonciji, Stomatološki fakultet, Sarajevo 2005.

[2] T. Graber, R. Vanarsdall, K.Vig, Current Principles and Techniques. Elsvier Mossby, St Louis 2005.

[3] A. Matropoulos, A. Karamouzos, it G. Kolokithas, E. Athanasiou, In vivo evaluation of two new moisture - resistant orthodontic adhesive systems: a comparative clinical trial. Journal of Orthodontics. 30 (2003) 139-147.

[4] S. Vilchis, R. Jose, Y. Seigo, K.Noriyuki, Shear bond strength of orthodontics brackets bonded with self-etching adhesives. Am J Orthod Dentofac Orthop. 136(3) (2009) 425-430.

[5] J. A. Foster, D. W. Berzins, T. G. Bradley. Bond strength of an amorphous calcium phosphatecontaining orthodontic adhesive. Angle Orthodontist. 78(2) (2008) 339-344.

[6] S. E. Bishara, D. Ortho, J.F. Laffoon, L.V. Wold, J. Warron, Effect of time on the shear bond strength of cyanoacrylate and composite orthodontic adhesives. Am J Orthod Dentofacial Orthop. 121 (2002) 297-300.

[7] S. E. Bishara, M. Salisman, J.F. Laffoon, J..Warren, Shear bond strength of a new high fluoride release glass ionomer adhesive. Angle Orthod. 78(1) (2008) 125-128.

[8] S. E. Bishara, M.E. Olsen, P. Damon. J.R. Jakobsen. Evaluation of a new light-cured orthodontic bonding adhesive. Am J Orthod Dentofacial Orthop. 114(1) (1998) 80-87. 
[9] S. B. Park, W.S. Son, C.C. Ko, S. GarciaGodoy, M.G. Park, H. Kim, Y.H. Kwon. Influence of flowable resin on the shear bond strength of orthodontic brackets. Dental Materials J. 28(6) (2009) 730-734.

[10] V. Mitić, M. Janošević, Uticaj vremena aplikacije ortofosforne kiseline na jačinu veze ortodontskih bravica na zub. Serbian Dental J. 55 (2008) 23-33.

[11] V. Mitić, Shear bond strength of orthodontic brackets bonded with GIC. Serbian Dental Journal. 56 (2009) 117-12.

[12] J. C. Dorminey, W. J. Dunn, L. J. Taloumis, Shear bond strength of orthodontic brackets bonded with a modified 1-step etchant and primer technique. Am. J. Orthod dentofacial Orthop. 124 (2003) 410-413.

[13] V. Mitić, A. Mitić, Lj. Čemerikić, M. Nišić, SEM izgled nagriženih bukalnih površina gledji zuba ortofosfornom kiselinom u različitim vremenskom intervalu. Acta Stomatologica Naissi. 51 (2005) 507-515.

[14] R. M. Walente, W. G. Rijk, J. L. Grummond, C. A. Evans. Etching conditions for resin-modified glass ionomer cement for orthordontic brackets. Am J Orthod Dentofacial Orthop 121 (2002) 516-520.

[15] S. E. Bishara, D. Ortho, J. F. Laffon, J. Warren, Effect of using a new cyanoacrylate adhesi$v e$ on the shear bond strength of orthodontic brackets. Angle Orthod. 71(6) (2001) 466-469.

[16] S. E. Bishara, A. W. Otsby, R. Ajlouni, J. Laffoon, J. Warren, A new premixed self-etch adhesive for bonding orthodontic brackets. Angle Orthod. 78(6) (2008) 1101-1004.

[17] S. E. Bishara, R. Ajlouni, C. Oonsombat, J. Laffon, Bonding orthodontic brackets to porcelain using different adhesives-enamel conditioners: a comparative study. World J Orthod. 6(1) (2005) $17-24$.

[18] A. B. Lifshitz, M. Cardenas. A comparison between the shear bond strength of brackets bonded to glazed and deglazed porcelain surfaces with resin-reinforced glass-ionomer cement and a bis-GMA resin adhesive. World J Orthod. 7(2) (2006) 134-137.

[19] P. D. Lowder, T. Foley, D. W. Banting. Bond strength of 4 orthodontic adhesives used with a caries - protective resin sealant. Am J Orthod Dentofacial Orthop. 134(2) (2008) 291-295.

[20] S. B. Pantović, G. L. Rosić, M. A. Rosić, M. Radosavljević, M. R. Kojić, J. R. Milovanović, A. P. Lučić, M. R. Radovanović, V. S. Zdravković. Advanced approach to biomechanical and functional tissue properties - new disign of applied hardware and software. Medicus. 6(1) (2006) 18-20.

[21] M. Rosić, S. Pantović, V. Ranković, Z. Obradović. N. Filipović, M. Kojić. Evaluation of dynamic response and biomechanical properties of isolated blood vesels. J Biochem Methods. 70 (2008) 966-972.

[22] E. Marković, B. Glišić, I. Šćepan, D. Marković, V. Jokanović. Bond strength of orthodontic adhesives. Journal of Metallurgy. 14(2) (2008) 73-88.

[23] M. L. Swartz, Orthodontic bonding. Orthod Select. 16 (2004) 1-4.

[24] R. G. Oliver. The effect of different methods of bracket removal on the amount of residual adhesive. Am J. Orthod Dentofacial Orthop. 93 (1988) 196-200.

[25] P. K. Sinha, R. S. Nanda, M. G. Duncanson, M. J. Hosier. Bond strengths and remnant adhesive resion on debonding for orthodontic bonding techniques. Am J. Orthod Dentofacial Orthop. 108 (1995) 302-7.

[26] K. S. Coups-Smith, P.E. Rossouw, K.C. Titley. Glass ionomer cements as luting agents for orthodontic brackets. Angle Orthod. 73 (2003) 43644.

[27] S. Howell, W.T. Weekes. An electron microscopid evaluation of the enamel surface subsequent to various debonding procedures. Aust Dent J. 35 (1990) 245-52.

[28] R.S. Hobson, A. J. Rugg-Gunn, S. D. Hogg. Bond strength to surface enamel for different tooth types. Dent Mater. 17 (2001) 184-9.

[29] G. V. Newman. First direct bonding in ortodontia. Am J. Orthod Dentofacial Orthop. 101 (1992) 190-192.

[30] G. V. Newman, R. A. Newman, A. K. Sengupta. Comparative assesment of light-cured resin-modified glass ionomer and composite resin adhesives: In vitro study of a new adhesive system. Am J. Orthod. Dentofacial Orthop. 119 (2001) 256-262. 
$\sin 8$

\section{CON TEC LC ФОТОПОЛИМЕРИЗУЈУЋИ АДХЕЗИВ У ОРТОДОНЦИЈИ}

Сажетак: У раду је анализиран фотополимеризујући адхезив Con Tec LC који је коришћен за бондирање брекета за зуб. Везивање адхезива започиње уз помоћ електромагнетног зрачења, односно ултравиолетне свјетлости. Примјена ових адхезива започела је осамдесетих година прошлог вијека.

За анализу јачине везе брекет-зуб (сила дебондирања по површини контакта брекет - глеђ зуба) коришћено је 40 екстрахираних зуба фронталне регије. Процес дебондирања постављених ортодонтских брекета у циљу одређивања величине силе која је потребна за одвајање бравице од површине зуба мјерена је помоћу једноосног Stretch System у Центру за биоинжењеринг Универзитета у Крагујевцу. Вучно оптерећење је остварено при константној брзини од $1 \mathrm{~mm} / \mathrm{min}$, а апарат је аутоматски биљежио силу са тачношћу од $0,3 \mathrm{~N}$. Након спроведеног истраживања добијени резултати су статистички обрађени и анализирани.

На крају спроведене анализе дати су клиничко-теоријске импликације истраживаног Con Tec LC адхезива.

Кључне ријечи: Con Tec LC, адхезив, ортодонција. 